\title{
ANALISIS SISTEM ANTRIAN PADA STASIUN PENGISIAN BAHAN BAKAR (SPBU) KOPKAR NUSA TIGA JL. SUNGGAL MEDAN
}

\author{
Oleh: \\ Anitha Paulina Tinambunan, SE, M.Si
}

\begin{abstract}
This study aims to analyze the model of queues at filling stations Kopkar Nusa Three Jl. Sunggal Medan using phase.Teknik single multi-channel data collection is done through observation and documentation. The study population was the whole vehicle wheel 2 (two) in the queuing system on weekdays applicable on Nusa Tiga Kopkar gas station Jl. Sunggal Medan. Sampling is done by nonprobability sampling Convenience sampling using primary data obtained from observation. So the data is taken against vehicles entering into the queuing system is running. From the analysis of the queuing system Kopkar Nusa Three gas station Jl. Terrain Sunggal known Poisson distributed arrival frequency, level of service and inter-arrival time is not exponentially. The level of visitor arrivals was obtained for 13 people per 8 minutes. This means that the server is quite crowded by the customer and the service provided is also capable of serving pelanggan. Waktu customers waiting in the queue $(W q)$ is 0871 minutes and still be within the maximum limit of the customer is willing to wait (time aspiration) that is equal to 15 minutes.
\end{abstract}

\section{Keywords: Queue System}

\section{PENDAHULUAN}

Dalam kehidupan sehari-hari setiap individu baik secara sadar maupun tidak sadar pasti pernah mengalami yang namanya antrian.Contoh-contoh kasus antrian dalam kehidupan sehari-hari misalnya antrian pembelian tiket bioskop, antrian pembelian BBM, antrian pasien yang sedang menunggu obat, antrian nasabah di BANK, dan masih banyak lagi.Barisan antri atau antrian adalah suatu fenomena yang terjadi apabila permintaan terhadap suatu pelayanan pada waktu tertentu melebihi kapasitas pelayanan pada waktu yang sama.

Sistem antrian merupakan salah satu unsur penting yang berpengaruh terhadap mutu pelayanan yang dirasakan oleh konsumen. Menunggu antrian yang panjang dapat disebabkan oleh kurangnya fasilitas untuk melayani masyarakat atau jumlah loket pelayanan yang ada belum memadai untuk melayani masyarakat, serta kurang sigapnya para pelayanan untuk melayani masyarakat atau konsumen. Beberapa faktor yang harus dipertimbangkan dalam melakukan analisis sistem antrian adalah disiplin antrian, asal pelanggan, tingkat kedatangan dan tingkat pelayanan. Disiplin antrian mengacu pada urutan berapa lama seorang pelanggan menunggu untuk dilayani. Dalam hal ini, pelanggan menginginkan agar mereka yang datang lebih awal dilayani terlebih dahulu.Tingkat pelayanan mengacu pada jumlah konsumen yang dilayani per satuan waktu.

Pembahasan teori antrian lebih difokuskan pada upaya penguraian waktu tunggu yang terjadi dalam barisan antrian. Tujuan dasar dari model-model antrian adalah meminimumkan sekaligus dua biaya, yakni biaya langsung untuk menyediakan pelayanan dan biaya individu yang menunggu untuk memperoleh pelayanan. Perbedaan antara jumlah permintaan terhadap fasilitas pelayananan dan kemampuan fasilitas untuk melayani menimbulkan dua konsekuensi logis, yaitu timbulnya antrian dan timbulnya pengangguran kapasitas. Antrian yang panjang karena kemampuan fasilitas pelayanan lebih rendah dari jumlah pemakainya, jelas akan memunculkan garis tunggu, sehingga mereka yang antri atau berada di garis tunggu itu akan menanggung opportunity cost. Sejauh oppurtunity cost itu negatif, maka mereka mungkin bersedia untuk tetap berada di garis tunggu. Namun 
sebaliknya, mereka pasti akan keluar dari garis tunggu dan itu berarti kerugian. Disisi lain, penyediaan kapasitas pelayanan yang terlalu berlebihan menyebabkan tingkat penggunaan fasilitas rendah, jelas akan menaikkan biaya rata-rata.

Hasil penelitian Awang Herli di SPBU No. 64-75364 Sangatta Samarinda menyimpulkan bahwa fasilitas pompa pengisian bahan bakar tidak disesuaikan dengan kebutuhan, khususnya pompa pengisian bahan bakar solar. Penelitian Marshel Sahab dkk dengan judul Analisis Antrian SPBU 64-78118 Jl. Hasanudin Pontianak menyimpulkan pengisian bahan bakar oleh kendaraan berat (truk barang/bis antar kota/tronton) pada jamjam sibuk mengakibatkan kemacetan karena antrian yang cukup panjang dan menggunakan lebar jalan Hasanudin Pontianak.

Antrian terbentuk karena jumlah konsumen yang tiba pada fungsi pelayanan melebihi kapasitas pelayan yang tersedia. Hal ini menunjukkan bahwa kapasitas pelayanan yang disediakan oleh perusahaan tidak mampu melayani konsumen yang datang.Antrian juga terjadi karena kedatangan pelanggan tidak pada tingkat yang sama dan waktu yang dibutuhkan untuk melayani pelanggan juga tidak sama. Dalam jangka panjang, antrian yang terbentuk semakin panjang dan berkurang akan mendekati suatu tingkat kedatangan rata-rata dan tingkat pelayanan rata-rata.

Antrian pada sistem pengisian bahan bakar premium ini paling mendominasi antrian kendaraan seluruh sistem yang ada, sehingga tepat melakukan penelitian untuk menganalisis antrian pada SPBU Kopkar Nusa Tiga Jl. Sunggal Medan, guna mengetahui apakah tingkat pelayanan yang diberikan oleh pihak SPBU sudah optimal dengan tingkat kedatangan kendaraan rata-rata yang memasuki sistem. Berdasarkan pengamatanpendahuluandi SPBU Kopkar Nusa Tiga Jalan Sunggal Medan diketahui adanya antrian yang panjang dan tidak adanya antrian pada selang waktu tak tentu. Antrian yang panjang tersebut diakibatkan oleh kecepatan kerja para server yang kurang sehingga pelanggan merasa bosan menunggu giliran untuk mendapatkan pelayanan. Sedangkan tidak adanya antrian pada selang waktu tak tentu mengakibatkan terjadinya idle pada operator pada saat tidak ada antrian.

Menunggu dalam suatu antrian merupakan suatu hal yang sering terjadi dalam kehidupan sehari-hari. Antrian terjadi akibat tidak seimbangnya antara jumlah pelayanan yang tersedia dengan jumlah kedatangan pelanggan. Dua parameter utama model antrian adalah tingkat kedatangan dan tingkat pelayanan. Memperbaiki pelayanan dengan mengurangi waktu menunggu juga semakin penting karena meningkatnya penekanan pada kualitas, terutama pada usaha yang terkait dengan pelayanan. Dengan memperhatikan hal ini, banyak perusahaan yang menjadikan usaha untuk mengurangi waktu menunggu sebagai komponen utama perbaikan kualitas mereka.

Penelitian ini memiliki beberapa batasan masalah yang terlebih dahulu dipertegas oleh peneliti yakni :

1. Kendaraan yang menjadi objek penelitian adalah kendaraan roda 2 (dua).

2. Pengambilan data hanya dilakukan untuk mengamati waktu kedatangan, waktu keluar dan waktu pelayanan

3. Pengamatan hanya dilakukan selama 5 jam dalam sehari dari pukul 08.30-12.30 WIB, dan hanya dilakukan untuk 3 hari pengamatan yaitu hari Selasa, Rabu dan Kamis.

4. Pada pengamatan ini server yang diamati terdiri dari 2 server

5. Disiplin pelayanan yang dipakai adalah dengan disiplin First In First Out (FIFO).

Berdasarkan batasan masalah di atas dapat dirumuskan masalah penelitian sebagai berikut:“Bagaimana analisis model antrian pada SPBU Kopkar Nusa Tiga Jl. Sunggal Medan?"

Penelitian ini bertujuan untuk menganalisis model antrian di SPBU Kopkar Nusa Tiga Jl. Sunggal Medan dengan menggunakan metode multi chanel single phase.Manfaat penelitian :Memberikan informasi kepada perusahaan mengenai analisis sistem antrian. dan 
agi peneliti lain, dapat dijadikan sebagai referensi dalam melakukan penelitian yang berkaitan dengan manajemen operasional khususnya sistem antrian.

\section{Pengertian dan Proses Dasar Antrian}

Sistem antrian atau sering disebut sebagai waiting line theory diciptakan pada tahun 1990 oleh seorang matematikawan dan insinyur berkebangsaan Denmark yang bernama A.K. Erlang yang mempelajari fluktuasi permintaan fasilitas telepon dan keterlambatan pelayanannya.

Teori antrian adalah teori yang menyangkut studi matematis dari antrian atau barisbaris penungguan. Formasi baris-baris penungguan ini tentu saja merupakan suatu fenomena yang biasa terjadi apabila kebutuhan akan suatu pelayanan melebihi kapasitas yang tersedia untuk menyelenggarakan pelayanan itu.

Suatu proses antrian (queueing process) adalah suatu proses yang berhubungan dengan kedatangan seorang pelanggan pada suatu fasilitas pelayanan, kemudian menunggu dalam suatu baris (antrian) jika semua pelayannya sibuk, dan akhirnya meninggalkan fasilitas tersebut. Sebuah sistem antrian adalah suatu himpunan pelanggan, pelayan, dan suatu aturan yang mengatur kedatangan para pelanggan.Sistem antrian itu sendiri adalah suatu keadaan sistem pelayanan dimana waktu kedatangan lebih besar dari pada waktu pelayanan. Sistem antrian dapat diklasifikasikan menjadi sistem yang berbedabeda dimana teori antrian diterapkan secara luas, yakni :

1. sistem pelayanan komersialcontoh: restoran, cafetaria, toko-toko, salon.

2. sistem pelayanan bisnis industri contoh : lini produksi, system material hadling, sistem penggudangan.

3. sistem pelayanan transportasicontoh : kereta api, bis, pesawat terbang.

4. sistem pelayanan sosialcontoh : kantor tenaga kerja, kantor registrasi SIM dan STNK.

Tujuan dasar model-model antrian adalah untuk meminumkan biaya total, yaitu: a) biaya langsung yang meliputi: biaya karena menambah fasilitas layanan; gaji tenaga kerja yang memberi pelayanan dan b) biaya tidak langsung yakni biaya karena mengantri (biaya yang timbul karena para individu harus menunggu untuk dilayani).Sistem antriandapat digambarkan sebagai berikut(http://ghostyoen.files.wordpress.com/2008/02/simulasiantrian.pdf)

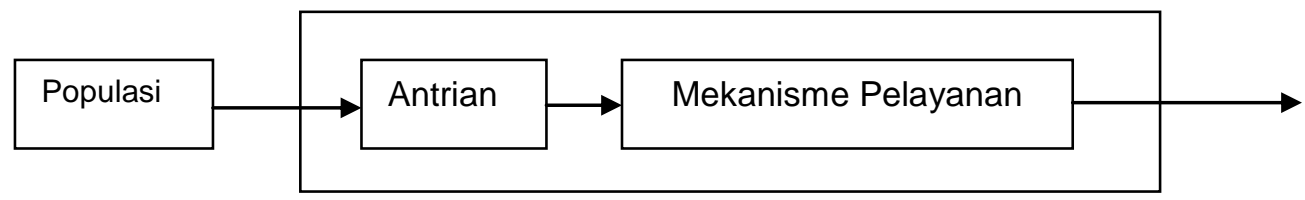

\section{Gambar 1. Proses Dasar Antrian}

Komponen dasar proses antrian yaitu:

1. Kedatangan. Setiap masalah antrian melibatkan kedatangan, misalnya orang, mobil, panggilan telepon untuk dilayani, dan lain - lain. Cara terjadinya kedatangan yang umumnya merupakan variabel acak.

2. Pelayan. Pelayan atau mekanisme pelayanan dapat terdiri dari satu atau lebih pelayan, atau satu atau lebih fasilitas pelayanan. Tiap - tiap fasilitas pelayanan kadang- kadang disebut sebagai saluran (channel).

3. Antri. Inti dari analisa antrian adalah antri itu sendiri. Timbulnya antrian terutama tergantung dari sifat kedatangan dan proses pelayanan. Penentu antrian lain yang penting adalah disiplin antri. Disiplin antri adalah aturan keputusan yang menjelaskan cara melayani pengantri. Beberapa bentuk disiplin pelayanan yang biasa digunakan, yaitu : 
a. First Come First Served (FCFS) atau First In First Out (FIFO) artinya, lebihdulu datang (sampai), lebih dulu dilayani (keluar). Misalnya, antrian padaloket pembelian tiket bioskop.

b. Last Come First Served (LCFS) atau Last In First Out (LIFO) artinya, yangtiba terakhir yang lebih dulu keluar. Misalnya, sistem antrian dalam elevator untuk lantai yang sama.

c. Service In Random Order (SIRO) artinya, panggilan didasarkan pada peluang secara random, tidak soal siapa yang lebih dulu tiba.

d. Priority Service (PS) artinya, prioritas pelayanan diberikan kepada pelanggan yang mempunyai prioritas lebih tinggi dibandingkan dengan pelanggan yang mempunyai prioritas lebih rendah, meskipun yang terakhir ini kemungkinan sudah lebih dahulu tiba dalam garis tunggu. Kejadian seperti ini kemungkinan disebabkan oleh beberapa hal, misalnya seseorang yang dalam keadaan penyakit lebih berat dibanding dengan orang lain dalam suatu tempat praktek dokter.

Dalam hal di atas telah dinyatakan bahwa entitas yang berada dalam garis tunggu tetap tinggal di sana sampai dilayani. Hal ini bisa saja tidak terjadi. Misalnya, seorang pembeli bisa menjadi tidak sabar menunggu antrian dan meninggalkan antrian. Untuk entitas yang meninggalkan antrian sebelum dilayani digunakan istilah pengingkaran (reneging). Pengingkaran dapat bergantung pada panjang garis tunggu atau lama waktu tunggu. Istilah penolakan (balking) dipakai untuk menjelaskan entitas yang menolak untuk bergabung dalam garis tunggu.

\section{Model Struktur Antrian}

Proses yang terjadi pada proses antrian dapat digambarkan sebagai berikut

Unit-unit yang

membutuhkan

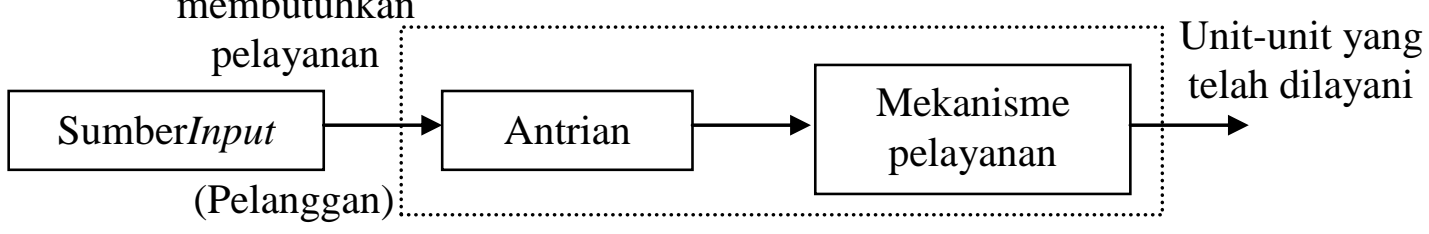

Sistem antrian

\section{Gambar 2. Struktur Dasar Antrian}

Struktur dasar model antrian adalah:

1. Sumber (Populasi). Salah satu karakteristik dari sumber yang perlu diketahui adalah ukuran populasi yaitu jumlah pelanggan yang memerlukan pelayanan dari waktu ke waktu. Misalnya jumlah pelanggan listrik di wilayah A yang berkewajiban melakukan melakukan pembayaran rekening listrik setiap bulan di wilayah tersebut.

2. Kedatangan Pelanggan. Pola distribusi kedatangan pelanggan ke dalam sistem menentukan pola besarnya kedatangan pelanggan dalam sistem. Suatu anggapan yang dapat dibuat adalah kedatangan pelanggan ke dalam sistem selalu mengikuti proses Poisson.

3. Barisan Antri. Suatu antrian selalu ditandai dari besarnya jumlah pelanggan yang ada dalam sistem antrian untuk mendapatkan pelayanan.

4. Disiplin Pelayanan. Disiplin antrian yang umum dikenal ialah first come, first served artinya siapa yang duluan datang, maka dia berhak dilayani terlebih dahulu. Disiplin pelayanan yang lain ialah last come, firstserved yaitu yang belakangan datang akan dilayani terlebih dahulu. 
5. Mekanisme Pelayanan. Jika sistem mempunyai lebih dari satu stasiun pelayanan yang paralel, maka beberapa pelanggan dapat dilayani secara simultan. Suatu model antrian disebut model pelayanan tunggal apabila sistem hanya mempunyai satu stasiun pelayanan dan disebut model pelayanan ganda apabila sistem mempunyai sejumlah stasiun pelayanan yang paralel yang masing-masing dilayani oleh seorang pelayan.

6. Kepergian Pelanggan. Waktu yang dibutuhkan untuk pelayanan sejak pelayanan dimulai hingga selesai disebut waktu pelayanan. Seperti halnya pada kedatangan pelanggan, waktu pelayanan ini juga mempunyai distribusi probabilitas yang ditentukan berdasarkan sampling dari keadaan yang sebenarnya.

Menurut Pangestu Subagyo,dkk (2002) terdapat 4 model struktur antrian dasar yang umum terjadi dalam seluruh sistem antrian, yaitu :

1. Single Channel-Single Phase(Model : M/M/I/I/I)

Single Channel berarti hanya ada satu jalur yang memasuki sistem pelayanan atau ada satu fasilitas pelayanan. Single phase menunjukan bahwa hanya ada satu station pelayanan atau sekumpulan tunggal operasi yang dilaksanakan. Contoh : antri beli tiket/kasir, dll.

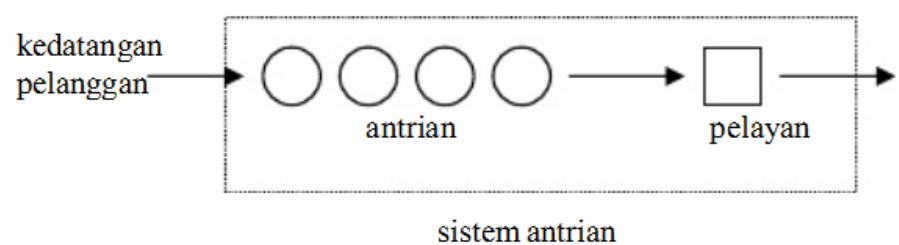

Gambar 3. Model Single Channel - Single Phase

2. Multi Channel - Single Phase(Model : M/M/I/I/F)

Sistem Multi Channel - Single Phase terjadi kapan saja di mana ada dua atau lebih fasilitas pelayanan dialiri oleh antrian tunggal, sebagai contoh model ini adalah antrian pada teller sebuah bank.

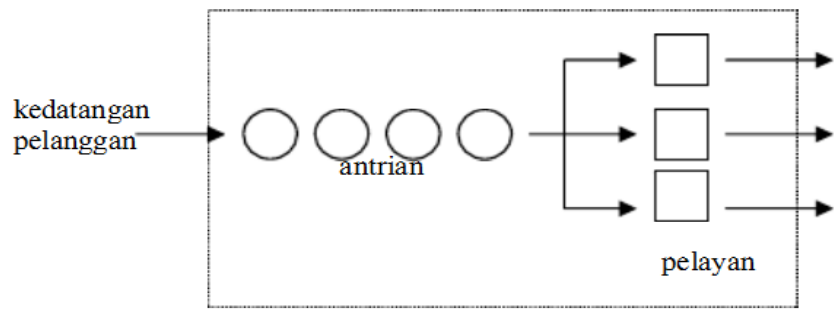

sistem antrian

Gambar 4. Model Multi Channel -Single Phase 
3. Single Channel - Multi Phase(Model : M/M/S/I/I)

Istilah Multi Phase menunjukkan ada dua atau lebih pelayanan yang dilaksanakan secara berurutan (dalam fase-fase). Sebagai contoh: pencucian mobil.

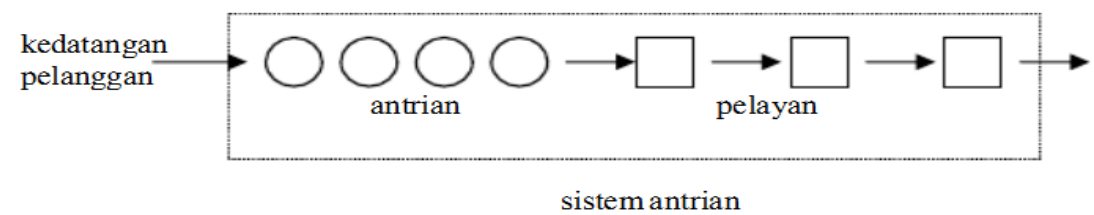

Gambar 5. Model Single Channel - Multi Phase

4. Multi Channel - Multi Phase(Model : M/M/S/F/I)

Sistem Multi Channel - Multi Phase ditunjukkan dalam Gambar 6.Sistem ini mempunyai beberapa fasilitas pelayanan pada setiap tahap, sehingga lebih dari satu individu dapat dilayani pada suatu waktu. Sebagai contoh, registrasi para mahasiswa di universitas, pelayanan kepada pasien di rumah sakit mulai dari pendaftaran, diagnosa, penyembuhan sampai pembayaran. Setiap sistem - sistem ini mempunyai beberapa fasilitas pelayanan pada setiap tahapnya.

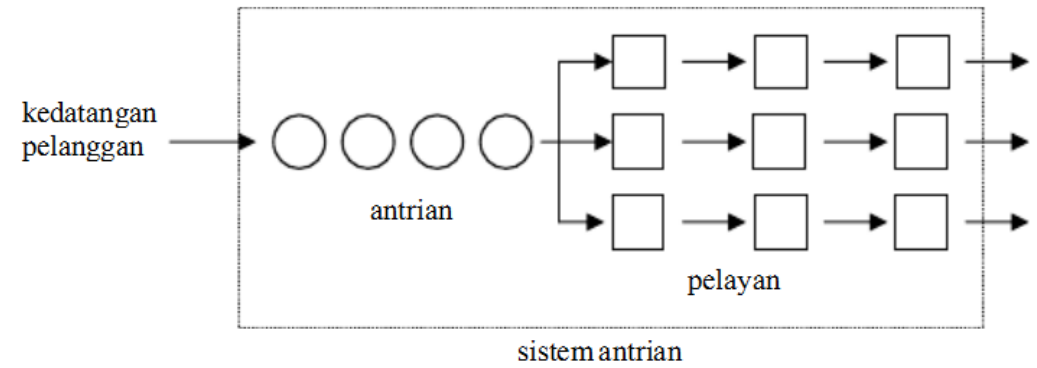

Gambar 6. Model Multi Channel - Multi Phase

Menurut Taylor III $(2005,200)$ sistem antrian pelayanan terdiri dari: 1$)$ sistem antrian pelayanan tunggal dan 2) sistem antrian pelayanan multipel.

\section{Sistem Antrian Pelayanan Tunggal(Single Channel Model)}

Pelayanan tunggal dengan sebuah antrian tunggal merupakan bentuk paling sederhana dari sistem antrian. Komponen dari suatu metode antrian adalah kedatangan, pelayanan dan struktur antrian. Faktor-faktor penting yang harus dipertimbangkan dalam melakukan analisis sistem antrian adalah:

a. Disiplin antrian (pada urutan berapa konsumen dilayani). Disiplin antrian adalah urutan di mana para konsumen yang menunggu akan dilayani. Konsumen dilayani atas dasar datang, pertama dilayani. Artinya, orang yang pertama berada dalam antrian akan dilayani lebih dulu. Ini adalah jenis disiplin antrian yang paling umum. Kadangkala konsumen dilayani sesuai dengan perjanjian terlebih dahulu antara pihak produsen dengan konsumen.

b. Sifat populasi konsumen (dari mana konsumen berasal). Populasi konsumen atau populasi panggilan adalah sumber atau asal konsumen yang datang ke pasar. Dalam kasus ini diasumsikan tidak terbatas. Dengan kata lain, sejumlah besar konsumen di daerah lokasi tersebuit merupakan jumlah konsumen potensial yang diasumsikan tidak terhingga.

c. Tingkat kedatangan (seberapa sering konsumen ada dalam antrian). Tingkat kedatangan adalah tingkat di mana para konsumen datang ke suatu fasilitas jasa selama periode waktu tertentu. Tingkat ini dapat diperkirakan berdasarkan data empiris yang diambil 
dari hasil mempelajari sistem tersebut atau mempelajari suatu sistem yang sama, atau dapat dianggap sebagai nilai rata-rata dari data empiris tersebut.

d. Tingkat pelayanan (seberapa cepat konsumen dilayani). Tingkat pelayanan adalah ratarata jumlah konsumen yang dapat dilayani selama periode waktu tertentu. Suatu tingkat pelayanan adalah serupa dengan tingkat kedatangan yaitu merupakan suatu variabel acak. Dengan kata lain, faktor-faktor seperti perbedaan jumlah pembelian konsumen, jumlah kembalian yang harus dihitung kasir dan perbedaan bentuk pembayaran mengubah jumlah konsumen yang dapat dilayani.

Suatu model antrian sederhana mempunyai karakteristik sebagai berikut:

1. Waktu datangnya pekerjaan dapat dinyatakan polanya sebagai distribusi Poisson.

2. Waktu pelayanan dapat dinyatakan polanya sebagai distribusi eksponensial.

3. Single fasilitas pelayanan.

4. Disiplin antrian berdasarkan First Come First Served.

Rumus dasar model antriannya adalah :

- Probabilitas tidak adanya pelanggan dalam suatu sistem antrian (Po)

$$
\text { Po }=1-\frac{\lambda}{\mu}
$$

- Probabilitas terdapat $\mathrm{n}$ pelanggan dalam suatu sistem antrian/faktor utilisasi system/ Pn

$$
\operatorname{Pn}=\frac{\lambda}{\mu}
$$

- Rata-rata jumlah pelanggan dalam suatu sistem antrian (yaitu jumlah pelanggan yang dilayani dan yang berada dalam baris antrian) (L)

$$
\mathrm{L}=\frac{\lambda}{\mu-\lambda}
$$

- Rata-rata jumlah pelanggan yang berada dalam barisan antrian (Lq)

$\mathrm{Lq}=\frac{\lambda^{2}}{\mu(\mu-\lambda)}$

- Rata-rata waktu yang dihabiskan seorang pelanggan dalam keseluruhan sistem antrian (yaitu waktu untuk menunggu dan dilayani) (W)

$$
\mathrm{W}=\frac{1}{(\mu-\lambda)}=\frac{\mathrm{L}}{\lambda}
$$

- Waktu rata-rata yang dihabiskan untuk menunggu dalam antrian (Wq)

$\mathrm{Wq}=\frac{\lambda}{0(\mu-\lambda)}$

- Probabilitas bahwa pelayan sedang sibuk (yaitu probabilitas seoarng pelanggan harus menunggu), dikenal dengan faktor utilisasi (U)

$\mathrm{U}=\frac{\lambda}{\mathrm{\theta}}$

- Probabilitas pelayan menganggur (probabilitas seorang pelanggan dapat dilayani) (I)

$$
\mathrm{I}=1-\mathrm{U}=1-\frac{\lambda}{\mathrm{g}}
$$

Pernyataan terakhir ini, $1-(\lambda / \mu)$, juga sama dengan Po. Probabilitas tidak adanya pelanggan dalam sistem antrian adalah sama dengan probabilitas menganggurnya pelayan.

\section{Sistem Antrian Pelayanan Multipel(Multiple-Channel Model)}

Dalam Multiple-Channel Model, fasilitas yang dimiliki lebih dari satu. Huruf (s) menyatakan jumlah fasilitas pelayanan .Sistem $\mathrm{M} / \mathrm{M} / \mathrm{s}$ adalah suatu proses antrian yang memiliki suatu pola kedatangan Poisson dengan ciri-ciri sebagai berikut : jumlah pelayan 
sebanyak s yang tidak saling bergantung tetapi waktu pelayanan dari masing-masingnya adalah identik mengikuti pola distribusi Eksponensial (yang mana tidakbergantung pada keadaan sistem), kapasitasnya berhingga dan disiplin antriannya adalah FIFO.

Adapun rumus-rumus perhitungan yang digunakan dalam sistem antrian populasi tidak terbatas dengan pelayanan majemuk $(\mathrm{M} / \mathrm{M} / \mathrm{s})$ adalah sebagai berikut:

1. Probalitas tidak ada pelanggan yang menunggu $\left(P_{n}\right)$ :

a. Bila $0 \leq \mathrm{n} \leq \mathrm{s}$

$$
P_{n}=\frac{(\mu / \mu)^{n}}{n !} P_{0}
$$

b. Bila $\mathrm{n} \geq \mathrm{s}$

$$
\begin{aligned}
\mathrm{P}_{\mathrm{n}}=\frac{(\lambda / \mu)^{\mathrm{n}}}{\mathrm{s} ! \mathrm{s}^{\mathrm{n}-\mathrm{s}}} \mathrm{P}_{0} & \\
\text { dimana : } & \mathrm{P}_{\mathrm{n}}=\text { Probabilitas n pelanggan yang menunggu } \\
\mathrm{s} & =\text { Banyaknya server dalam satu jalur } \\
\lambda & =\text { Jumlah kedatangan rata-rata per satuan waktu } \\
\mu & =\text { Jumlah rata-rata yang dilayani per satuan waktu pada setiap jalur }
\end{aligned}
$$

2. Rata-rata Jumlah Pelanggan Dalam Sistem (L)

$$
\begin{aligned}
& \mathrm{L}_{\mathrm{s}}=\mathrm{L}_{\mathrm{q}}+\frac{\lambda}{\mu} \\
& \text { dimana }: \mathrm{L}_{\mathrm{s}}=\text { Jumlah rata-rata pelanggan dalam sistem } \\
& \mathrm{L}_{\mathrm{q}}=\text { Jumlah rata-rata pelanggan dalam antrian } \\
& \lambda=\text { Jumlah kedatangan rata-rata per satuan waktu } \\
& \mu=\text { Jumlah rata-rata yang dilayani per satuan waktu pada setiap jalur }
\end{aligned}
$$

3. Rata-rata Jumlah Pelanggan Dalam Antrian $\left(\mathrm{L}_{\mathrm{q}}\right)$

$$
\mathrm{L}_{\mathrm{q}}=\frac{\mathrm{P}_{0}(\lambda \mu)^{\mathrm{s}} \rho}{\mathrm{s} !(1-\rho)^{2}}
$$

dimana : $\mathrm{L}_{\mathrm{q}}=$ Jumlah rata-rata pelanggan dalam antrian

$\mathrm{s} \quad=$ Banyaknya server dalam satu jalur

$\lambda=$ Jumlah kedatangan rata-rata per satuan waktu

$\mu \quad=$ Jumlah rata-rata yang dilayani per satuan waktu pada setiap jalur

$\mathrm{r} \quad=$ Utilisasi server $=1 / \mathrm{s} . \mathrm{m}$

4. Rata-rata Waktu yang Dihabiskan Satu Pelanggan dalam Antrian $\left(\mathrm{W}_{\mathrm{q}}\right)$

$$
\begin{array}{rll}
\mathrm{W}_{\mathrm{q}}=\frac{\mathrm{L}_{\mathrm{q}}}{\lambda} & \ldots \ldots \ldots \ldots \ldots \ldots \ldots \ldots \ldots \ldots \ldots \ldots \ldots \ldots \ldots \ldots \ldots \ldots \ldots \ldots \ldots \ldots \ldots \ldots \ldots \ldots \ldots \ldots \ldots \ldots \ldots \ldots \ldots \\
\text { dimana }: & \mathrm{L}_{\mathrm{q}} & =\text { Jumlah rata-rata pelanggan dalam antrian } \\
\lambda & =\text { Jumlah kedatangan rata-rata per satuan waktu } \\
\mathrm{W}_{\mathrm{q}} & =\text { Rata-rata waktu pelanggan dalam antrian }
\end{array}
$$

5. Rata-rata Waktu yang Dihabiskan Satu Pelanggan dalam Sistem (W)

$$
\mathrm{W}_{\mathrm{s}}=\mathrm{W}_{\mathrm{q}}+\frac{1}{\mu}
$$

dimana: $\mathrm{W}_{\mathrm{s}}$ = Rata-rata waktu pelanggan dalam system

$\mu \quad=$ Jumlah rata-rata yang dilayani per satuan waktu pada setiap jalur

$\mathrm{W}_{\mathrm{q}}=$ Rata-rata waktu pelanggan dalam antri 


\section{METODE PENELITIAN}

\section{Populasi dan Sampel}

Populasi merupakan keseluruhan objek yang akan diteliti. Populasi penelitian ini adalah seluruh kendaraan roda 2 (dua) dalam sistem antrian pada hari kerja yang berlaku pada SPBU Kopkar Nusa Tiga Jl. Sunggal, Medan.

Sampel yang akan diambil adalah jumlah pelanggan dalam antrian padapukul 08.3012.30 WIB, dan hanya dilakukan untuk 3 hari pengamatan yaitu hari Selasa, Rabu dan Kamis.Teknik sampling dilakukan dengan nonprobability sampling yaitu convenience sampling dengan menggunakan data primer yang diperoleh dari observasi. Jadi data diambil terhadap kendaraan yang masuk ke sistem antrian yang sedang berjalan.

\section{Metode dan Pengumpulan Data}

Data yang dibutuhkan dalam penelitian ini diperoleh melalui 2 cara yakni:

1. Observasi yaitu melakukan pengamatan secara langsung terhadap objek penelitian.di lapangan untuk mengetahui sistem antrian pelanggan.

2. Teknik dokumentasi, dilakukan dengan mengumpulkan data yang sudah diolah sebelumnya berupa kedatangan pelanggan, tingkat pelayanan, jumlah pelayan dan ratarata pelayanan efektif

\section{Teknik Analisis Data}

Penelitian ini merupakan penelitian kuantitatif sehingga semua permasalahan akan dianalisis dengan pendekatan matematis. Alat analisis yang digunakan adalah model multi channel single phase yaitu metode yang digunakan untuk dua atau lebih fasilitas pelayanan (server) yang dialiri oleh antrian tunggal. Formula untuk karakteristik operasi model pelayanan multi channel single phase adalah:

\section{Menghitung Rata-rata Tingkat Kedatangan Pelanggan}

$(\lambda)=\frac{N}{I}$

Dimana: $\mathrm{N}=$ Jumlah pelanggan

I = Interval waktu

2. Menghitung Rata-rata Tingkat Pelayanan

$\bar{X}=\frac{\Sigma \mathrm{xi}^{*} \text { oi }}{\Sigma \text { oi }}$

Tingkat pelayanan $(\mu)=\frac{1}{\text { rata-rata pelayanan } 1 \text { hari }} x$ Interval waktu

3. Menghitung Tingkat Utilisasi Sistem

$$
\begin{aligned}
& \rho=\frac{\lambda}{c \mu} \\
& \text { dimana : } \rho=\text { tingkat utilitas sistem } \\
& \lambda=\text { tingkat kedatangan } \\
& \mu=\text { tingkat pelayanan } \\
& c \quad=\text { jumlah Server }
\end{aligned}
$$

4. Menghitung probabilitas tidak terdapatnya pelanggan di dalam sistem:

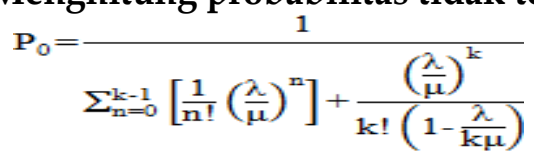

dimana : $\quad \mathrm{P}_{0}=$ probabilitas tidak adanya pelanggan dalam sistem

$\mu \quad=$ rata-rata tingkat pelayanan

$\lambda=$ rata-rata tingkat kedatangan

$\mathrm{k}=$ jumlah fasilitas/Server 


\section{Menghitung Rata-rata Waktu Pengunjung dalam Antrian}

$$
W q=\frac{\lambda^{2} \mu^{-2}\left(\frac{\lambda}{\mu}\right)^{k-1}}{2(k-1) !\left(k-\frac{\lambda}{\mu}\right)^{2}\left[\sum_{n=0}^{k-1} \frac{\left(\frac{\lambda}{\mu}\right)^{n}}{n !}+\frac{\left(\frac{\lambda}{\mu}\right)^{k}}{(k-1) !\left(k-\frac{\lambda}{\mu}\right)}\right]}
$$

dimana: $\quad \mathrm{W}_{\mathrm{q}}=$ waktu pelayanan dalam garis antrian

$\mu \quad=$ rata-rata tingkat pelayanan pelanggan

$\lambda \quad=$ rata-rata tingkat kedatangan pelanggan

$\mathrm{k} \quad=$ jumlah Server

6. Menghitung Rata-rata Jumlah Pengunjung dalam Antrian

$L q=\lambda(W q)$

dimana : $\quad \mathrm{Lq}=$ Jumlah pelanggan di dalam garis antrian

$\lambda \quad=$ rata-rata tingkat kedatangan pelanggan

$\mathrm{Wq}=$ waktu pelayanan dalam garis antrian

\section{Waktu rata-rata pelanggan di dalam suatu sistem}

$$
\begin{aligned}
& W s=W q+\frac{1}{\mu} \ldots \ldots \ldots \ldots \ldots \ldots \ldots \ldots \ldots \ldots \ldots \ldots \ldots \ldots \ldots \ldots \ldots \ldots \ldots \ldots \ldots \ldots \ldots \ldots \\
& \text { dimana : } W s=\text { waktu pelayanan di dalam sistem } \\
& W q=\text { waktu pelayanan dalam garis antrian } \\
& \mu \quad=\text { rata-rata tingkat pelayanan pelanggan }
\end{aligned}
$$

8. Menghitung Rata-rata Jumlah Pengunjung dalam Sistem

$L s=\lambda(W s)$

dimana: Ls = jumlah pengunjung dalam sistem

$\lambda \quad=$ rata-rata tingkat kedatangan pelanggan

$\mathrm{W}=$ waktu pelayanan dalam sistem

\section{Hasil Penelitian dan Pembahasan}

Sistem antrian yang diamati adalah SPBUKopkar Nusa Tiga yang berlokasi di Jalan Sunggal Medan. SPBU Kopkar Nusa Tiga memiliki 2 Server. Pada sistem ini pelanggan yang pertama datang yang lebih dulu dilayani (keluar). Jumlah pelanggan dan populasi pada sistem antrian SPBU Kopkar Nusa Tiga adalah tidak terbatas.

Batasan sistem antrian pada sistem antrian SPBUKopkar Nusa Tigaadalah

1. WaktuKedatangan : Waktu pelanggan memasuki batasan antrian

2. Waktu Pelayanan : Waktu pelanggan dilayani oleh pelayan server

3. Waktu Keluar : Waktu pelanggan selesai dilayani server

Pengamatan dilakukan selama 8 jam dalam sehari. Aturan pelayanan yang diberikan oleh petugas SPBUKopkar Nusa Tiga adalah FIFO (First In First Out), yang berarti bahwa pelanggan yang lebih dulu datang (sampai), lebih dulu dilayani (keluar).

Sistem antrian SPBU Kopkar Nusa Tiga memiliki sistem normal dengan frekuensi kedatangan berdistribusi Poisson, tingkat pelayanan dan waktu antar kedatangan tidak berdistribusi eksponensial. Hasil pengamatan terhadap frekuensi kedatangan dalam selang waktu 8 menit adalah sebagai berikut: 


\begin{tabular}{|c|c|c|c|c|c|c|}
\hline \multirow{2}{*}{$\begin{array}{c}\text { No } \\
1\end{array}$} & \multicolumn{3}{|c|}{ Interval Waktu } & \multirow{2}{*}{ Server 1} & \multirow{2}{*}{$\begin{array}{c}\text { Server } 2 \\
4\end{array}$} & \multirow{2}{*}{$\begin{array}{c}\text { Jumlah Pelanggan } \\
8\end{array}$} \\
\hline & 12:30:00 & - & 12:38:00 & & & \\
\hline 2 & $12: 38: 00$ & - & $12: 46: 00$ & 9 & 9 & 18 \\
\hline 3 & $12: 46: 00$ & - & $12: 54: 00$ & 7 & 7 & 14 \\
\hline 4 & $12: 54: 00$ & - & 13:02:00 & 7 & 6 & 13 \\
\hline 5 & 13:02:00 & - & $13: 10: 00$ & 8 & 8 & 16 \\
\hline 6 & 13:10:00 & - & 13:18:00 & 7 & 7 & 14 \\
\hline 7 & $13: 18: 00$ & - & $13: 26: 00$ & 7 & 8 & 15 \\
\hline 8 & $13: 26: 00$ & - & 13:34:00 & 6 & 5 & 11 \\
\hline 9 & $13: 34: 00$ & - & $13: 42: 00$ & 5 & 5 & 10 \\
\hline 10 & $13: 42: 00$ & - & $13: 50: 00$ & 4 & 4 & 8 \\
\hline 11 & $13: 50: 00$ & - & $13: 58: 00$ & 8 & 7 & 15 \\
\hline 12 & $13: 58: 00$ & - & $14: 06: 00$ & 6 & 7 & 13 \\
\hline 13 & $14: 06: 00$ & - & $14: 14: 00$ & 8 & 7 & 15 \\
\hline 14 & $14: 14: 00$ & - & $14: 22: 00$ & 6 & 7 & 13 \\
\hline 15 & $14: 22: 00$ & - & $14: 30: 00$ & 3 & 3 & 6 \\
\hline 16 & $14: 30: 00$ & - & $14: 38: 00$ & 9 & 9 & 18 \\
\hline 17 & $14: 38: 00$ & - & $14: 46: 00$ & 5 & 7 & 12 \\
\hline 18 & $14: 46: 00$ & - & $14: 54: 00$ & 6 & 2 & 8 \\
\hline 19 & $14: 54: 00$ & - & $15: 02: 00$ & 4 & 5 & 9 \\
\hline 20 & 15:02:00 & - & $15: 10: 00$ & 4 & 6 & 10 \\
\hline 21 & $15: 10: 00$ & - & $15: 18: 00$ & 4 & 5 & 9 \\
\hline 22 & $15: 18: 00$ & - & $15: 26: 00$ & 5 & 4 & 9 \\
\hline 23 & 15:26:00 & - & $15: 34: 00$ & 5 & 5 & 10 \\
\hline 24 & $15: 34: 00$ & - & $15: 42: 00$ & 4 & 4 & 8 \\
\hline 25 & $15: 42: 00$ & - & $15: 50: 00$ & 4 & 4 & 8 \\
\hline 26 & $15: 50: 00$ & - & $15: 58: 00$ & 7 & 5 & 12 \\
\hline 27 & 15:58:00 & - & 16:06:00 & 6 & 6 & 12 \\
\hline 28 & 16:06:00 & - & 16:14:00 & 6 & 9 & 15 \\
\hline 29 & $16: 14: 00$ & - & $16: 22: 00$ & 7 & 6 & 13 \\
\hline 30 & $16: 22: 00$ & - & $16: 30: 00$ & 6 & 5 & 11 \\
\hline 31 & $16: 30: 00$ & - & $16: 38: 00$ & 4 & 4 & 8 \\
\hline 32 & $16: 38: 00$ & - & $16: 46: 00$ & 5 & 3 & 8 \\
\hline 33 & 16:46:00 & - & $16: 54: 00$ & 6 & 6 & 12 \\
\hline 34 & $16: 54: 00$ & - & $17: 02: 00$ & 12 & 11 & 23 \\
\hline 35 & $17: 02: 00$ & - & $17: 10: 00$ & 11 & 12 & 23 \\
\hline 36 & 17:10:00 & - & 17:18:00 & 11 & 10 & 21 \\
\hline 37 & $17: 18: 00$ & - & $17: 26: 00$ & 13 & 12 & 25 \\
\hline 38 & $17: 26: 00$ & - & $17: 34: 00$ & 12 & 12 & 24 \\
\hline 39 & $17: 34: 00$ & - & $17: 42: 00$ & 13 & 12 & 25 \\
\hline 40 & $17: 42: 00$ & - & $17: 50: 00$ & 12 & 11 & 23 \\
\hline 41 & $17: 50: 00$ & - & $17: 58: 00$ & 9 & 12 & 21 \\
\hline 42 & $17: 58: 00$ & - & $18: 06: 00$ & 10 & 11 & 21 \\
\hline 43 & $18: 06: 00$ & - & $18: 14: 00$ & 9 & 8 & 17 \\
\hline 44 & 18:14:00 & - & 18:22:00 & 9 & 9 & 18 \\
\hline 45 & $18: 22: 00$ & - & $18: 30: 00$ & 11 & 10 & 21 \\
\hline 46 & 18:30:00 & - & $18: 38: 00$ & 9 & 9 & 18 \\
\hline 47 & $18: 38: 00$ & - & $18: 46: 00$ & 11 & 11 & 22 \\
\hline 48 & $18: 46: 00$ & - & $18: 54: 00$ & 4 & 3 & 7 \\
\hline 49 & $18: 54: 00$ & - & 19:02:00 & 4 & 5 & 9 \\
\hline 50 & 19:02:00 & - & 19:10:00 & 3 & 4 & 7 \\
\hline 51 & 19:10:00 & - & 19:18:00 & 4 & 5 & 9 \\
\hline 52 & $19: 18: 00$ & - & $19: 26: 00$ & 4 & 5 & 9 \\
\hline 53 & $19: 26: 00$ & - & 19:34:00 & 6 & 3 & 9 \\
\hline 54 & $19: 34: 00$ & - & $19: 42: 00$ & 4 & 4 & 8 \\
\hline 55 & $19: 42: 00$ & - & $19: 50: 00$ & 4 & 5 & 9 \\
\hline 56 & $19: 50: 00$ & - & $19: 58: 00$ & 4 & 3 & 7 \\
\hline 57 & $19: 58: 00$ & - & 20:06:00 & 5 & 5 & 10 \\
\hline 58 & 20:06:00 & - & 20:14:00 & 5 & 3 & 8 \\
\hline 59 & $20: 14: 00$ & - & $20: 22: 00$ & 2 & 3 & 5 \\
\hline 60 & $20: 22: 00$ & - & $20: 30: 00$ & 0 & 0 & 0 \\
\hline
\end{tabular}




\section{Menghitung Rata-rata Tingkat Kedatangan Pelanggan}

$$
\begin{gathered}
\lambda=\frac{N}{I} \quad \lambda=\frac{780}{60}=13 \\
=13 \text { orang per } 8 \text { menit } \\
=1.625 \approx 2 \text { orang per menit } \\
=97.5 \approx 98 \text { orang per jam }
\end{gathered}
$$

Dari keterangan ini dapat dilihat bahwa model antrian pada sistem antrian SPBU Kopkar Nusa Tiga adalah :

$$
\text { (M/G/2):(FIFO/16/œ). }
$$

Keterangan:

M : Tingkat kedatangan berdistribusi Poisson

G : Tingkat pelayanan tidak berdistribusi Eksponensial

2 : Jumlah Server $=2$

FIFO : Disiplin antrian First In First Out

\begin{tabular}{|c|c|c|c|}
\hline No. & Start & Finish & Idle \\
\hline 2 & 12:32:04 & 12:32:41 & $0: 00: 00$ \\
\hline 5 & 12:39:05 & 12:39:21 & 0:01:57 \\
\hline 6 & 12:39:48 & $12: 40: 37$ & $0: 00: 28$ \\
\hline 7 & 12:40:37 & $12: 41: 20$ & 0:00:00 \\
\hline 9 & 12:42:26 & 12:43:11 & 0:00:38 \\
\hline 10 & 12:43:13 & $12: 43: 53$ & 0:00:01 \\
\hline 11 & 12:43:53 & 12:45:06 & 0:00:00 \\
\hline 14 & 12:48:39 & $12: 48: 59$ & 0:00:00 \\
\hline 15 & 12:48:59 & $12: 50: 12$ & 0:00:00 \\
\hline 17 & 12:53:53 & $12: 55: 30$ & $0: 00: 22$ \\
\hline 21 & 13:02:11 & 13:02:36 & $0: 00: 00$ \\
\hline 22 & 13:02:36 & 13:04:19 & 0:00:00 \\
\hline 24 & 13:05:50 & 13:06:39 & 0:00:00 \\
\hline 27 & 13:07:39 & 13:09:09 & 0:00:00 \\
\hline 29 & $13: 10: 20$ & 13:10:40 & 0:00:00 \\
\hline 31 & 13:10:54 & 13:12:15 & 0:00:00 \\
\hline 32 & 13:12:15 & 13:13:14 & 0:00:00 \\
\hline 34 & 13:14:16 & 13:15:10 & 0:00:00 \\
\hline 36 & 13:16:12 & 13:17:25 & 0:00:00 \\
\hline 37 & 13:17:25 & 13:18:51 & 0:00:00 \\
\hline 38 & 13:18:51 & 13:20:18 & 0:00:00 \\
\hline 41 & 13:24:54 & 13:25:06 & 0:00:14 \\
\hline 43 & 13:27:09 & 13:28:29 & 0:00:00 \\
\hline 45 & 13:30:17 & 13:30:44 & 0:00:00 \\
\hline 46 & 13:30:44 & 13:32:01 & 0:00:00 \\
\hline 48 & 13:32:21 & 13:33:24 & $0: 00: 00$ \\
\hline 49 & 13:33:24 & 13:36:23 & 0:00:00 \\
\hline
\end{tabular}

16 : Pelanggan yang bisa masuk ke dalam sistem

$\infty \quad$ : Populasi tak terbatas

Iddle dari setiap Server yaitu selisih start pelanggan yang datang dengan finish pelanggan sebelumnya.

Tabel 2. Hasil IdleServer 1 


\begin{tabular}{|c|c|c|c|}
\hline 50 & $13: 37: 02$ & $13: 37: 42$ & $0: 00: 39$ \\
\hline 51 & $13: 38: 12$ & $13: 39: 11$ & $0: 00: 30$ \\
\hline 52 & $13: 39: 11$ & $13: 40: 27$ & $0: 00: 00$ \\
\hline 55 & $13: 42: 12$ & $13: 42: 57$ & $0: 00: 00$ \\
\hline 56 & $13: 42: 57$ & $13: 43: 30$ & $0: 00: 00$ \\
\hline 57 & $13: 47: 26$ & $13: 48: 09$ & $0: 03: 55$ \\
\hline 59 & $13: 50: 35$ & $13: 51: 15$ & $0: 00: 00$ \\
\hline 60 & $13: 53: 25$ & $13: 54: 05$ & $0: 02: 10$ \\
\hline 65 & $14: 01: 00$ & $14: 01: 06$ & $0: 01: 13$ \\
\hline 66 & $14: 01: 37$ & $14: 01: 56$ & $0: 00: 30$ \\
\hline 67 & $14: 02: 44$ & $14: 04: 03$ & $0: 00: 48$ \\
\hline 68 & $14: 04: 03$ & $14: 04: 26$ & $0: 00: 00$ \\
\hline
\end{tabular}

Tabel 2. Hasil IdleServer 1 ( Lanjutan 1 )

\begin{tabular}{|c|c|c|c|}
\hline No. & Start & Finish & Idle \\
\hline 71 & $14: 07: 31$ & $14: 07: 49$ & $0: 00: 21$ \\
\hline 74 & $14: 10: 22$ & $14: 12: 21$ & $0: 00: 00$ \\
\hline 75 & $14: 12: 21$ & $14: 12: 47$ & $0: 00: 00$ \\
\hline 77 & $14: 13: 45$ & $14: 14: 50$ & $0: 00: 00$ \\
\hline 80 & $14: 16: 54$ & $14: 17: 44$ & $0: 00: 00$ \\
\hline 81 & $14: 17: 44$ & $14: 19: 55$ & $0: 00: 00$ \\
\hline 83 & $14: 21: 35$ & $14: 22: 58$ & $0: 00: 20$ \\
\hline 84 & $14: 22: 58$ & $14: 23: 43$ & $0: 00: 00$ \\
\hline 89 & $14: 30: 39$ & $14: 30: 49$ & $0: 00: 00$ \\
\hline 91 & $14: 34: 04$ & $14: 35: 28$ & $0: 00: 00$ \\
\hline 94 & $14: 38: 06$ & $14: 39: 19$ & $0: 00: 30$ \\
\hline 95 & $14: 39: 33$ & $14: 40: 12$ & $0: 00: 14$ \\
\hline 100 & $14: 46: 05$ & $14: 46: 21$ & $0: 00: 00$ \\
\hline 102 & $14: 48: 36$ & $14: 49: 51$ & $0: 00: 33$ \\
\hline 109 & $15: 04: 53$ & $15: 05: 42$ & $0: 00: 11$ \\
\hline 135 & $15: 42: 25$ & $15: 43: 47$ & $0: 01: 17$ \\
\hline 138 & $15: 46: 57$ & $15: 48: 39$ & $0: 00: 00$ \\
\hline 140 & $15: 50: 46$ & $15: 51: 09$ & $0: 01: 27$ \\
\hline 141 & $15: 51: 09$ & $15: 52: 32$ & $0: 00: 00$ \\
\hline 142 & $15: 52: 32$ & $15: 52: 38$ & $0: 00: 00$ \\
\hline 143 & $15: 53: 25$ & $15: 55: 09$ & $0: 00: 47$ \\
\hline 146 & $16: 00: 14$ & $16: 01: 56$ & $0: 00: 01$ \\
\hline 148 & $16: 02: 29$ & $16: 03: 37$ & $0: 00: 00$ \\
\hline 150 & $16: 03: 53$ & $16: 04: 40$ & $0: 00: 00$ \\
\hline & Jumlah & & $0: 24: 39$ \\
\hline
\end{tabular}

Sumber: SPBU Kopkar Nusa Tiga Medan

Tabel 3. Hasil IdleServer 2

\begin{tabular}{|c|c|c|c|}
\hline No. & Start & Finish & Idle \\
\hline 1 & $12: 30: 35$ & $12: 32: 04$ & $0: 00: 00$ \\
\hline
\end{tabular}




\begin{tabular}{|c|c|c|c|}
\hline 3 & 12:34:18 & $12: 35: 45$ & $0: 01: 37$ \\
\hline 4 & $12: 36: 46$ & $12: 37: 08$ & $0: 01: 01$ \\
\hline 8 & $12: 41: 27$ & 12:41:47 & 0:00:08 \\
\hline 12 & 12:46:17 & $12: 47: 12$ & $0: 01: 11$ \\
\hline 13 & $12: 47: 39$ & $12: 48: 39$ & $0: 00: 27$ \\
\hline 16 & $12: 53: 11$ & $12: 53: 31$ & $0: 02: 59$ \\
\hline 18 & $12: 55: 30$ & $12: 55: 57$ & 0:00:00 \\
\hline 19 & $12: 56: 55$ & $12: 57: 03$ & $0: 00: 58$ \\
\hline 20 & $13: 00: 25$ & 13:02:11 & $0: 03: 23$ \\
\hline 23 & 13:04:19 & $13: 05: 50$ & 0:00:00 \\
\hline 25 & 13:06:39 & 13:06:49 & 0:00:00 \\
\hline 26 & 13:06:49 & $13: 07: 39$ & $0: 00: 00$ \\
\hline 28 & 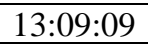 & $13: 10: 20$ & $0: 00: 00$ \\
\hline 30 & $13: 10: 40$ & $13: 10: 54$ & 0:00:00 \\
\hline 33 & $13: 13: 14$ & $13: 14: 16$ & 0:00:00 \\
\hline 35 & $13: 15: 10$ & $13: 16: 12$ & $0: 00: 00$ \\
\hline 39 & $13: 21: 20$ & 13:22:09 & $0: 01: 01$ \\
\hline 40 & $13: 22: 55$ & $13: 24: 40$ & $0: 00: 46$ \\
\hline 42 & $13: 25: 59$ & 13:27:09 & $0: 00: 54$ \\
\hline 44 & $13: 28: 29$ & 13:30:17 & $0: 00: 00$ \\
\hline 47 & $13: 32: 01$ & $13: 32: 21$ & 0:00:00 \\
\hline 53 & $13: 40: 27$ & $13: 41: 31$ & 0:00:00 \\
\hline 54 & 13:41:31 & $13: 42: 12$ & 0:00:00 \\
\hline 58 & 13:48:11 & $13: 50: 35$ & $0: 00: 02$ \\
\hline 61 & $13: 56: 07$ & $13: 57: 26$ & $0: 02: 02$ \\
\hline 63 & $13: 58: 50$ & $13: 59: 07$ & 0:00:00 \\
\hline 64 & 13:59:07 & $13: 59: 48$ & 0:00:00 \\
\hline 69 & $14: 04: 26$ & 14:06:02 & $0: 00: 00$ \\
\hline 70 & 14:06:02 & 14:07:10 & 0:00:00 \\
\hline 72 & $14: 07: 49$ & 14:07:56 & $0: 00: 00$ \\
\hline 73 & 14:09:39 & $14: 10: 22$ & $0: 01: 43$ \\
\hline 76 & $14: 12: 47$ & $14: 13: 45$ & $0: 00: 00$ \\
\hline 78 & 14:14:50 & $14: 15: 44$ & $0: 00: 00$ \\
\hline 79 & $14: 15: 53$ & $14: 16: 54$ & 0:00:09 \\
\hline 82 & $14: 19: 55$ & $14: 21: 15$ & $0: 00: 00$ \\
\hline 85 & $14: 23: 43$ & $14: 24: 35$ & $0: 00: 00$ \\
\hline 86 & $14: 24: 35$ & $14: 25: 34$ & $0: 00: 00$ \\
\hline 87 & $14: 25: 34$ & $14: 26: 26$ & 0:00:00 \\
\hline 88 & 14:30:01 & $14: 30: 39$ & $0: 03: 35$ \\
\hline 90 & 14:32:08 & $14: 34: 04$ & $0: 01: 18$ \\
\hline 92 & $14: 35: 56$ & $14: 36: 32$ & $0: 00: 28$ \\
\hline 93 & $14: 36: 33$ & $14: 37: 36$ & $0: 00: 01$ \\
\hline 96 & $14: 40: 45$ & 14:40:58 & $0: 00: 33$ \\
\hline 97 & $14: 42: 20$ & 14:43:01 & $0: 01: 22$ \\
\hline 98 & 14:43:01 & 14:43:47 & $0: 00: 00$ \\
\hline 99 & $14: 45: 08$ & 14:46:05 & $0: 01: 22$ \\
\hline 101 & $14: 46: 21$ & $14: 48: 04$ & $0: 00: 00$ \\
\hline 103 & $14: 58: 03$ & $14: 58: 49$ & $0: 08: 12$ \\
\hline 105 & 15:01:50 & $15: 02: 21$ & $0: 02: 31$ \\
\hline 106 & 15:02:21 & 15:03:28 & $0: 00: 00$ \\
\hline 107 & 15:03:28 & 15:04:35 & 0:00:00 \\
\hline
\end{tabular}


Tabel 5.3. Hasil IdleServer 2 (Lanjutan )

\begin{tabular}{|c|c|c|c|}
\hline No. & Start & Finish & Idle \\
\hline 108 & $15: 04: 35$ & $15: 04: 43$ & $0: 00: 00$ \\
\hline 114 & $15: 09: 24$ & $15: 10: 30$ & $0: 00: 00$ \\
\hline 115 & $15: 10: 30$ & $15: 11: 06$ & $0: 00: 00$ \\
\hline 118 & $15: 13: 12$ & $15: 14: 10$ & $0: 00: 00$ \\
\hline 119 & $15: 17: 58$ & $15: 18: 33$ & $0: 03: 49$ \\
\hline 121 & $15: 20: 38$ & $15: 21: 58$ & $0: 00: 00$ \\
\hline 124 & $15: 24: 42$ & $15: 25: 58$ & $0: 00: 00$ \\
\hline 125 & $15: 25: 58$ & $15: 26: 45$ & $0: 00: 00$ \\
\hline 126 & $15: 26: 45$ & $15: 28: 18$ & $0: 00: 00$ \\
\hline 127 & $15: 28: 18$ & $15: 28: 21$ & $0: 00: 00$ \\
\hline 128 & $15: 29: 31$ & $15: 29: 50$ & $0: 01: 11$ \\
\hline 131 & $15: 32: 45$ & $15: 33: 08$ & $0: 00: 00$ \\
\hline 133 & $15: 37: 02$ & $15: 45: 38$ & $0: 02: 59$ \\
\hline 136 & $15: 44: 01$ & $15: 46: 57$ & $0: 00: 14$ \\
\hline 137 & $15: 46: 26$ & $15: 49: 19$ & $0: 00: 49$ \\
\hline 139 & $15: 48: 39$ & $15: 55: 40$ & $0: 00: 00$ \\
\hline 144 & $15: 55: 09$ & $16: 00: 13$ & $0: 03: 55$ \\
\hline 145 & $15: 59: 35$ & $16: 02: 29$ & $0: 00: 00$ \\
\hline 147 & $16: 01: 56$ & $16: 03: 53$ & $0: 00: 00$ \\
\hline 149 & $16: 03: 37$ & & $0: 50: 39$ \\
\hline
\end{tabular}

Sumber: SPBU Kopkar Nusa Tiga Medan

\section{Menghitung Tingkat Utilisasi Sistem}

$$
\begin{aligned}
& \rho=\frac{\lambda}{c \mu} \\
& \rho=\frac{\lambda}{c \mu}=\frac{1.625}{2 \times 1.6154}=0.5030 \\
& \% \rho=\rho \times 100 \% \\
& \% \rho=0.5030 \times 100 \% \\
& \% \rho=50.3 \%
\end{aligned}
$$

Nilai tingkat utilitas sistem antrian tersebut adalah 0.5030 atau $50.3 \%$.

Sedangkan probabilitas tidak terdapatnya pelanggan di dalam sistem menggunakan rumus di berikut :

$$
\mathrm{P}_{0}=\frac{1}{\sum_{\mathrm{n}=0}^{\mathrm{k}-1}\left[\frac{1}{\mathrm{n} !}\left(\frac{\lambda}{\mu}\right)^{\mathrm{n}}\right]+\frac{\left(\frac{\lambda}{\mu}\right)^{\mathrm{k}}}{\mathrm{k} !\left(1-\frac{\lambda}{\mathrm{k} \mu}\right)}}
$$

1

$$
P o=\frac{1}{\left[\frac{1}{0 !}\left(\frac{1.625}{1.6154}\right)^{0}+\frac{1}{1 !}\left(\frac{1.625}{1.6154}\right)^{1}\right]+\frac{\left(\frac{1.625}{1.6154}\right)^{2}}{2 !\left(1-\frac{1.625}{2 \times 1.6154}\right)}}
$$

Po $=0.3307$

Po $(\%)=0.3307 \times 100 \%=33.07 \%$ 
Tabel 4. Data Waktu Kedatangan, Waktu \& Lama Pelayanan

\begin{tabular}{|c|c|c|c|c|c|c|}
\hline \multirow{2}{*}{ No. } & \multirow{2}{*}{$\begin{array}{c}\text { Waktu } \\
\text { Kedatangan }\end{array}$} & \multicolumn{2}{|c|}{ Waktu Pelayanan } & \multirow{2}{*}{$\begin{array}{l}\text { Waktu } \\
\text { Keluar }\end{array}$} & \multirow{2}{*}{$\begin{array}{c}\text { Lama } \\
\text { Pelayanan }\end{array}$} & \multirow{2}{*}{ Menit } \\
\hline & & Server 1 & Server 2 & & & \\
\hline 1 & $12: 30: 35$ & & $12: 30: 35$ & $12: 32: 04$ & $0: 01: 29$ & 2.0340 \\
\hline 2 & $12: 31: 04$ & $12: 32: 04$ & & $12: 32: 41$ & $0: 00: 37$ & 0.6338 \\
\hline 3 & $12: 34: 18$ & & $12: 34: 18$ & $12: 35: 45$ & $0: 01: 27$ & 0.0285 \\
\hline 4 & $12: 36: 46$ & & $12: 36: 46$ & $12: 37: 08$ & $0: 00: 22$ & 0.6929 \\
\hline 5 & $12: 39: 05$ & $12: 39: 05$ & & $12: 39: 21$ & $0: 00: 15$ & 0.0857 \\
\hline 6 & $12: 39: 48$ & $12: 39: 48$ & & $12: 40: 37$ & $0: 00: 49$ & 0.6403 \\
\hline 7 & $12: 40: 32$ & $12: 40: 37$ & & $12: 41: 20$ & $0: 00: 42$ & 0.4776 \\
\hline 8 & $12: 41: 27$ & & $12: 41: 27$ & $12: 41: 47$ & $0: 00: 20$ & 0.3470 \\
\hline 9 & $12: 42: 26$ & $12: 42: 26$ & & $12: 43: 11$ & $0: 00: 46$ & 0.3905 \\
\hline 10 & $12: 43: 13$ & $12: 43: 13$ & & $12: 43: 53$ & 0:00:41 & 0.0491 \\
\hline 11 & $12: 43: 38$ & $12: 43: 53$ & & $12: 45: 06$ & $0: 01: 13$ & 0.2263 \\
\hline 12 & $12: 46: 17$ & & $12: 46: 17$ & $12: 47: 12$ & $0: 00: 55$ & 0.1049 \\
\hline 13 & $12: 47: 39$ & & $12: 47: 39$ & $12: 48: 39$ & $0: 01: 00$ & 1.1503 \\
\hline 14 & $12: 48: 04$ & $12: 48: 39$ & & $12: 48: 59$ & $0: 00: 20$ & 1.8497 \\
\hline 15 & $12: 48: 50$ & $12: 48: 59$ & & $12: 50: 12$ & $0: 01: 13$ & 1.0568 \\
\hline 16 & $12: 53: 11$ & & $12: 53: 11$ & $12: 53: 31$ & $0: 00: 20$ & 1.0467 \\
\hline 17 & $12: 53: 53$ & $12: 53: 53$ & & $12: 55: 30$ & $0: 01: 36$ & 0.7545 \\
\hline 18 & $12: 55: 14$ & & $12: 55: 30$ & $12: 55: 57$ & $0: 00: 27$ & 0.1508 \\
\hline 19 & $12: 56: 55$ & & $12: 56: 55$ & $12: 57: 03$ & 0:00:08 & 0.2013 \\
\hline 20 & $13: 00: 25$ & & $13: 00: 25$ & 13:02:11 & $0: 01: 46$ & 0.6980 \\
\hline 21 & 13:01:01 & 13:02:11 & & $13: 02: 36$ & $0: 00: 25$ & 0.5726 \\
\hline 22 & $13: 01: 21$ & $13: 02: 36$ & & 13:04:19 & $0: 01: 43$ & 0.9794 \\
\hline 23 & $13: 01: 33$ & & 13:04:19 & $13: 05: 50$ & $0: 01: 30$ & 1.1841 \\
\hline 24 & $13: 01: 57$ & $13: 05: 50$ & & 13:06:39 & $0: 00: 49$ & 1.9222 \\
\hline 25 & $13: 02: 52$ & & $13: 06: 39$ & $13: 06: 49$ & $0: 00: 10$ & 0.3355 \\
\hline 26 & $13: 03: 23$ & & $13: 06: 49$ & $13: 07: 39$ & $0: 00: 51$ & 0.1163 \\
\hline 27 & 13:04:30 & 13:07:39 & & 13:09:09 & $0: 01: 29$ & 0.3119 \\
\hline 28 & 13:05:31 & & 13:09:09 & $13: 10: 20$ & $0: 01: 11$ & 0.0181 \\
\hline 29 & $13: 06: 26$ & $13: 10: 20$ & & $13: 10: 40$ & $0: 00: 20$ & 0.2932 \\
\hline 30 & 13:07:03 & & $13: 10: 40$ & $13: 10: 54$ & $0: 00: 14$ & 0.2118 \\
\hline 31 & $13: 07: 25$ & $13: 10: 54$ & & $13: 12: 15$ & $0: 01: 20$ & 1.0155 \\
\hline 32 & $13: 07: 46$ & $13: 12: 15$ & & $13: 13: 14$ & $0: 00: 59$ & 1.0779 \\
\hline 33 & 13:09:14 & & 13:13:14 & $13: 14: 16$ & 0:01:02 & 0.2219 \\
\hline 34 & $13: 09: 51$ & $13: 14: 16$ & & $13: 15: 10$ & $0: 00: 55$ & 0.3036 \\
\hline 35 & $13: 11: 10$ & & $13: 15: 10$ & $13: 16: 12$ & 0:01:02 & 1.0305 \\
\hline 36 & $13: 13: 32$ & $13: 16: 12$ & & $13: 17: 25$ & $0: 01: 13$ & 0.4628 \\
\hline 37 & $13: 14: 21$ & $13: 17: 25$ & & $13: 18: 51$ & $0: 01: 25$ & 0.7161 \\
\hline 38 & $13: 17: 46$ & $13: 18: 51$ & & $13: 20: 18$ & $0: 01: 27$ & 0.0261 \\
\hline 39 & $13: 21: 20$ & & $13: 21: 20$ & $13: 22: 09$ & $0: 00: 49$ & 0.3906 \\
\hline 40 & $13: 22: 55$ & & $13: 22: 55$ & $13: 24: 40$ & $0: 01: 46$ & 0.1110 \\
\hline 41 & $13: 24: 54$ & $13: 24: 54$ & & $13: 25: 06$ & 0:00:11 & 0.6556 \\
\hline 42 & $13: 25: 59$ & & $13: 25: 59$ & $13: 27: 09$ & 0:01:09 & 1.0680 \\
\hline 43 & $13: 26: 48$ & $13: 27: 09$ & & $13: 28: 29$ & $0: 01: 21$ & 0.0695 \\
\hline 44 & $13: 28: 00$ & & $13: 28: 29$ & 13:30:17 & $0: 01: 48$ & 1.3899 \\
\hline 45 & $13: 28: 18$ & $13: 30: 17$ & & $13: 30: 44$ & $0: 00: 27$ & 0.0916 \\
\hline 46 & $13: 29: 49$ & $13: 30: 44$ & & 13:32:01 & $0: 01: 18$ & 0.1903 \\
\hline 47 & $13: 30: 35$ & & $13: 32: 01$ & $13: 32: 21$ & $0: 00: 20$ & 0.0855 \\
\hline 48 & $13: 31: 16$ & $13: 32: 21$ & & $13: 33: 24$ & $0: 01: 03$ & 0.0858 \\
\hline 49 & 13:32:01 & $13: 33: 24$ & & $13: 36: 23$ & $0: 02: 59$ & 0.0254 \\
\hline 50 & $13: 37: 02$ & $13: 37: 02$ & & $13: 37: 42$ & $0: 00: 39$ & 1.6279 \\
\hline 51 & $13: 38: 12$ & $13: 38: 12$ & & $13: 39: 11$ & $0: 00: 59$ & 1.2941 \\
\hline 52 & $13: 38: 24$ & $13: 39: 11$ & & $13: 40: 27$ & $0: 01: 15$ & 1.9440 \\
\hline 53 & $13: 38: 48$ & & $13: 40: 27$ & $13: 41: 31$ & $0: 01: 04$ & 1.0836 \\
\hline 54 & $13: 39: 50$ & & $13: 41: 31$ & $13: 42: 12$ & $0: 00: 41$ & 0.3228 \\
\hline 55 & $13: 40: 36$ & $13: 42: 12$ & & $13: 42: 57$ & $0: 00: 45$ & 0.4018 \\
\hline 56 & $13: 42: 06$ & $13: 42: 57$ & & $13: 43: 30$ & $0: 00: 34$ & 1.3872 \\
\hline 57 & $13: 47: 26$ & $13: 47: 26$ & & 13:48:09 & $0: 00: 43$ & 0.7094 \\
\hline 58 & $13: 48: 11$ & & $13: 48: 11$ & $13: 50: 35$ & $0: 02: 24$ & 0.5787 \\
\hline 59 & $13: 49: 16$ & $13: 50: 35$ & & $13: 51: 15$ & $0: 00: 39$ & 2.1267 \\
\hline
\end{tabular}

Tabel 4. Data Wkt Kedatangan; Wkt \& Lama Pelayanan (Lanjutan 1 )

\begin{tabular}{|c|c|c|c|c|c|}
\hline No. & Waktu & Waktu Pelayanan & Waktu & Lama & Menit \\
\hline
\end{tabular}




\begin{tabular}{|c|c|c|c|c|c|c|}
\hline & Kedatangan & Server 1 & Server 2 & Keluar & Pelayanan & \\
\hline 60 & $13: 53: 25$ & $13: 53: 25$ & & $13: 54: 05$ & 0:00:40 & 1.6092 \\
\hline 61 & $13: 56: 07$ & & $13: 56: 07$ & $13: 57: 26$ & $0: 01: 20$ & 0.3220 \\
\hline 62 & $13: 56: 26$ & $13: 57: 26$ & & $13: 58: 50$ & $0: 01: 23$ & 0.8719 \\
\hline 63 & 13:58:14 & & $13: 58: 50$ & 13:59:07 & $0: 00: 17$ & 1.4407 \\
\hline 64 & $13: 58: 21$ & & $13: 59: 07$ & $13: 59: 48$ & $0: 00: 41$ & 0.5418 \\
\hline 65 & 14:01:00 & 14:01:00 & & 14:01:06 & $0: 00: 06$ & 0.0880 \\
\hline 66 & $14: 01: 37$ & $14: 01: 37$ & & $14: 01: 56$ & $0: 00: 19$ & 0.1871 \\
\hline 67 & 14:02:44 & $14: 02: 44$ & & 14:04:03 & $0: 01: 19$ & 1.0135 \\
\hline 68 & $14: 03: 53$ & $14: 04: 03$ & & $14: 04: 26$ & $0: 00: 24$ & 1.0129 \\
\hline 69 & $14: 04: 12$ & & $14: 04: 26$ & 14:06:02 & $0: 01: 35$ & 0.6716 \\
\hline 70 & $14: 05: 35$ & & 14:06:02 & $14: 07: 10$ & 0:01:09 & 0.2499 \\
\hline 71 & $14: 07: 31$ & $14: 07: 31$ & & $14: 07: 49$ & $0: 00: 18$ & 0.1295 \\
\hline 72 & $14: 07: 47$ & & $14: 07: 49$ & $14: 07: 56$ & $0: 00: 07$ & 0.0414 \\
\hline 73 & 14:09:39 & & 14:09:39 & $14: 10: 22$ & $0: 00: 44$ & 0.8036 \\
\hline 74 & $14: 10: 19$ & $14: 10: 22$ & & $14: 12: 21$ & $0: 01: 58$ & 0.3469 \\
\hline 75 & $14: 12: 13$ & $14: 12: 21$ & & $14: 12: 47$ & $0: 00: 26$ & 0.1874 \\
\hline 76 & $14: 12: 35$ & & $14: 12: 47$ & $14: 13: 45$ & $0: 00: 58$ & 2.8216 \\
\hline 77 & $14: 13: 36$ & $14: 13: 45$ & & $14: 14: 50$ & $0: 01: 05$ & 2.5558 \\
\hline 78 & $14: 14: 11$ & & $14: 14: 50$ & $14: 15: 44$ & $0: 00: 54$ & 0.0063 \\
\hline 79 & $14: 15: 53$ & & $14: 15: 53$ & $14: 16: 54$ & $0: 01: 01$ & 0.5274 \\
\hline 80 & $14: 16: 30$ & $14: 16: 54$ & & $14: 17: 44$ & $0: 00: 50$ & 0.2148 \\
\hline 81 & $14: 17: 25$ & $14: 17: 44$ & & $14: 19: 55$ & $0: 02: 11$ & 1.8281 \\
\hline 82 & $14: 19: 52$ & & $14: 19: 55$ & $14: 21: 15$ & $0: 01: 20$ & 0.5251 \\
\hline 83 & $14: 21: 35$ & $14: 21: 35$ & & $14: 22: 58$ & $0: 01: 23$ & 0.3570 \\
\hline 84 & $14: 21: 59$ & $14: 22: 58$ & & $14: 23: 43$ & $0: 00: 45$ & 0.6278 \\
\hline 85 & $14: 22: 49$ & & $14: 23: 43$ & $14: 24: 35$ & $0: 00: 51$ & 1.1508 \\
\hline 86 & $14: 24: 04$ & & $14: 24: 35$ & $14: 25: 34$ & 0:01:00 & 0.8503 \\
\hline 87 & $14: 25: 19$ & & $14: 25: 34$ & $14: 26: 26$ & $0: 00: 52$ & 1.3249 \\
\hline 88 & 14:30:01 & & 14:30:01 & $14: 30: 39$ & $0: 00: 38$ & 0.0014 \\
\hline 89 & $14: 30: 32$ & $14: 30: 39$ & & $14: 30: 49$ & 0:00:10 & 0.2294 \\
\hline 90 & $14: 32: 08$ & & $14: 32: 08$ & $14: 34: 04$ & $0: 01: 56$ & 0.7534 \\
\hline 91 & $14: 33: 30$ & $14: 34: 04$ & & $14: 35: 28$ & $0: 01: 24$ & 0.8584 \\
\hline 92 & $14: 35: 56$ & & $14: 35: 56$ & $14: 36: 32$ & $0: 00: 36$ & 0.5233 \\
\hline 93 & $14: 36: 33$ & & $14: 36: 33$ & $14: 37: 36$ & $0: 01: 03$ & 0.5245 \\
\hline 94 & $14: 38: 06$ & $14: 38: 06$ & & $14: 39: 19$ & $0: 01: 13$ & 0.1795 \\
\hline 95 & $14: 39: 33$ & $14: 39: 33$ & & $14: 40: 12$ & $0: 00: 39$ & 0.4266 \\
\hline 96 & $14: 40: 45$ & & $14: 40: 45$ & $14: 40: 58$ & $0: 00: 13$ & 0.5909 \\
\hline 97 & $14: 42: 20$ & & $14: 42: 20$ & $14: 43: 01$ & $0: 00: 41$ & 0.2347 \\
\hline 98 & $14: 42: 40$ & & $14: 43: 01$ & $14: 43: 47$ & $0: 00: 46$ & 0.8836 \\
\hline 99 & $14: 45: 08$ & & $14: 45: 08$ & 14:46:05 & $0: 00: 57$ & 2.0340 \\
\hline 100 & $14: 45: 32$ & $14: 46: 05$ & & $14: 46: 21$ & $0: 00: 16$ & 1.4769 \\
\hline 101 & $14: 46: 10$ & & $14: 46: 21$ & $14: 48: 04$ & $0: 01: 42$ & 0.3514 \\
\hline 102 & $14: 48: 36$ & $14: 48: 36$ & & $14: 49: 51$ & $0: 01: 15$ & 0.1706 \\
\hline 103 & $14: 58: 03$ & & $14: 58: 03$ & $14: 58: 49$ & $0: 00: 46$ & 0.4417 \\
\hline 104 & $14: 58: 38$ & $14: 58: 49$ & & 14:59:18 & 0:00:29 & 0.0381 \\
\hline 105 & $15: 01: 50$ & & $15: 01: 50$ & $15: 02: 21$ & $0: 00: 32$ & 0.9489 \\
\hline 106 & $15: 02: 19$ & & $15: 02: 21$ & $15: 03: 28$ & $0: 01: 07$ & 0.1329 \\
\hline 107 & 15:03:07 & & 15:03:28 & $15: 04: 35$ & 0:01:07 & 1.0071 \\
\hline 108 & $15: 04: 18$ & & $15: 04: 35$ & $15: 04: 43$ & $0: 00: 08$ & 0.1637 \\
\hline 109 & $15: 04: 53$ & $15: 04: 53$ & & $15: 05: 42$ & $0: 00: 49$ & 0.0506 \\
\hline 110 & $15: 05: 27$ & $15: 05: 42$ & & $15: 06: 17$ & $0: 00: 35$ & 0.0075 \\
\hline 111 & 15:06:48 & $15: 06: 48$ & & 15:08:03 & $0: 01: 15$ & 0.2249 \\
\hline 112 & $15: 07: 52$ & $15: 08: 03$ & & $15: 08: 51$ & $0: 00: 48$ & 0.5659 \\
\hline 113 & 15:08:18 & $15: 08: 51$ & & 15:09:24 & $0: 00: 33$ & 0.8064 \\
\hline 114 & $15: 08: 36$ & & $15: 09: 24$ & $15: 10: 30$ & $0: 01: 06$ & 1.5349 \\
\hline 115 & $15: 09: 58$ & & $15: 10: 30$ & $15: 11: 06$ & $0: 00: 36$ & 0.3475 \\
\hline 116 & $15: 11: 44$ & $15: 11: 44$ & & $15: 12: 27$ & $0: 00: 44$ & 1.2349 \\
\hline 117 & $15: 12: 10$ & $15: 12: 27$ & & $15: 13: 12$ & $0: 00: 44$ & 1.1214 \\
\hline 118 & $15: 13: 01$ & & $15: 13: 12$ & $15: 14: 10$ & 0:00:58 & 0.2266 \\
\hline
\end{tabular}


Tabel 4. Data Wkt Kedatangan; Wkt \& Lama Pelayanan(Lanjutan 2)

\begin{tabular}{|c|c|c|c|c|c|c|}
\hline \multirow{2}{*}{ No. } & \multirow{2}{*}{$\begin{array}{c}\text { Waktu } \\
\text { Kedatangan }\end{array}$} & \multicolumn{2}{|c|}{ Waktu Pelayanan } & \multirow{2}{*}{$\begin{array}{l}\text { Waktu } \\
\text { Keluar }\end{array}$} & \multirow{2}{*}{$\begin{array}{c}\text { Lama } \\
\text { Pelayanan }\end{array}$} & \multirow{2}{*}{ Menit } \\
\hline & & Server 1 & Server 2 & & & \\
\hline 119 & $15: 17: 58$ & & $15: 17: 58$ & $15: 18: 33$ & $0: 00: 35$ & 1.2641 \\
\hline 120 & $15: 19: 19$ & 15:19:19 & & $15: 20: 38$ & $0: 01: 19$ & 0.5365 \\
\hline 121 & $15: 20: 27$ & & $15: 20: 38$ & $15: 21: 58$ & $0: 01: 20$ & 1.2436 \\
\hline 122 & $15: 21: 21$ & $15: 21: 58$ & & $15: 23: 55$ & $0: 01: 57$ & 0.5920 \\
\hline 123 & $15: 21: 44$ & $15: 23: 55$ & & $15: 24: 42$ & $0: 00: 47$ & 0.7346 \\
\hline 124 & $15: 22: 32$ & & $15: 24: 42$ & $15: 25: 58$ & $0: 01: 17$ & 0.7558 \\
\hline 125 & $15: 23: 26$ & & $15: 25: 58$ & $15: 26: 45$ & $0: 00: 47$ & 0.8033 \\
\hline 126 & $15: 24: 11$ & & $15: 26: 45$ & $15: 28: 18$ & $0: 01: 33$ & 0.1423 \\
\hline 127 & $15: 27: 53$ & & $15: 28: 18$ & $15: 28: 21$ & 0:00:03 & 0.0856 \\
\hline 128 & $15: 29: 31$ & & $15: 29: 31$ & $15: 29: 50$ & $0: 00: 19$ & 0.9843 \\
\hline 129 & $15: 30: 34$ & $15: 30: 34$ & & $15: 31: 27$ & $0: 00: 53$ & 0.9791 \\
\hline 130 & $15: 30: 48$ & $15: 31: 27$ & & $15: 32: 45$ & $0: 01: 18$ & 0.4875 \\
\hline 131 & $15: 31: 25$ & & $15: 32: 45$ & 15:33:08 & $0: 00: 23$ & 0.7237 \\
\hline 132 & $15: 31: 59$ & 15:33:08 & & $15: 34: 04$ & $0: 00: 56$ & 0.2323 \\
\hline 133 & $15: 37: 02$ & & $15: 37: 02$ & $15: 37: 43$ & 0:00:40 & 0.1757 \\
\hline 134 & $15: 40: 38$ & $15: 40: 38$ & & $15: 41: 09$ & $0: 00: 31$ & 0.0026 \\
\hline 135 & $15: 42: 25$ & $15: 42: 25$ & & $15: 43: 47$ & $0: 01: 22$ & 0.4838 \\
\hline 136 & $15: 44: 01$ & & $15: 44: 01$ & $15: 45: 38$ & $0: 01: 36$ & 1.2558 \\
\hline 137 & $15: 46: 26$ & & $15: 46: 26$ & $15: 46: 57$ & $0: 00: 31$ & 0.2784 \\
\hline 138 & $15: 46: 57$ & $15: 46: 57$ & & $15: 48: 39$ & $0: 01: 42$ & 0.9661 \\
\hline 139 & $15: 48: 35$ & & $15: 48: 39$ & $15: 49: 19$ & $0: 00: 40$ & 0.0033 \\
\hline 140 & $15: 50: 46$ & $15: 50: 46$ & & 15:51:09 & $0: 00: 23$ & 0.1048 \\
\hline 141 & $15: 51: 03$ & $15: 51: 09$ & & $15: 52: 32$ & $0: 01: 23$ & 0.4338 \\
\hline 142 & $15: 52: 05$ & $15: 52: 32$ & & $15: 52: 38$ & $0: 00: 06$ & 0.0487 \\
\hline 143 & $15: 53: 25$ & $15: 53: 25$ & & 15:55:09 & $0: 01: 44$ & 0.0296 \\
\hline 144 & $15: 54: 32$ & & 15:55:09 & $15: 55: 40$ & $0: 00: 32$ & 0.8977 \\
\hline 145 & $15: 59: 35$ & & $15: 59: 35$ & $16: 00: 13$ & $0: 00: 37$ & 0.5907 \\
\hline 146 & $16: 00: 14$ & $16: 00: 14$ & & 16:01:56 & $0: 01: 42$ & 0.0558 \\
\hline 147 & $16: 00: 20$ & & $16: 01: 56$ & $16: 02: 29$ & $0: 00: 34$ & 1.4520 \\
\hline 148 & $16: 00: 37$ & 16:02:29 & & $16: 03: 37$ & 0:01:08 & 1.2522 \\
\hline 149 & $16: 00: 45$ & & $16: 03: 37$ & $16: 03: 53$ & $0: 00: 15$ & 1.3058 \\
\hline 150 & $16: 00: 58$ & $16: 03: 53$ & & $16: 04: 40$ & $0: 00: 48$ & 0.8628 \\
\hline \multicolumn{6}{|c|}{ Jumlah } & 75.292 \\
\hline
\end{tabular}

Sumber : Data Diolah

\section{Menghitung Rata-rata Tingkat Pelayanan}

Tingkat pelayanan adalah rata-rata tingkat kemampuan Server untuk melayani pelanggan dalam suatu interval waktu yang dinotasikan dengan jumlah pelanggan per satuan interval waktu.

Waktu rata-rata pelayanan setiap pelanggan yang diperoleh dalam pengamatan ini adalah pembagian dari nilai $\mathrm{Xi}^{*} \mathrm{Oi}$ dibagi dengan $\mathrm{Oi}$. Contoh perhitungan pada tingkat pelayanan :

Tabel 5. Perhitungan nilai $\mathrm{Xi}^{*} \mathrm{Oi}$

\begin{tabular}{|r|r|c|c|c|c|r|r|}
\hline \multicolumn{2}{|c|}{ Interval } & BKB & BKA & $\mathbf{X i}$ & Oi & $\mathbf{X i}^{*} \mathbf{O} \mathbf{~}$ \\
\hline 0.033 & - & 0.349 & 0.033 & 0.349 & 0.192 & 291 & 55.813 \\
\hline 0.349 & - & 0.665 & 0.349 & 0.665 & 0.508 & 185 & 93.969 \\
\hline 0.666 & - & 0.982 & 0.666 & 0.982 & 0.824 & 185 & 152.456 \\
\hline 0.982 & - & 1.298 & 0.982 & 1.298 & 1.140 & 5 & 5.701 \\
\hline 1.298 & - & 1.614 & 1.298 & 1.614 & 1.456 & 102 & 148.550 \\
\hline 1.614 & - & 1.930 & 1.614 & 1.930 & 1.773 & 5 & 8.863 \\
\hline 1.930 & - & 2.246 & 1.930 & 2.246 & 2.089 & 2 & 4.177 \\
\hline 2.246 & - & 2.562 & 2.246 & 2.562 & 2.405 & 3 & 7.214 \\
\hline 2.562 & - & 2.879 & 2.562 & 2.879 & 2.721 & 1 & 2.721 \\
\hline 2.879 & - & 3.195 & 2.879 & 3.195 & 3.037 & 0 & 0.000 \\
\hline 3.195 & - & 3.195 & 3.195 & 3.195 & 3.195 & 1 & 3.195 \\
\hline
\end{tabular}

Sumber: Data Diolah 
$\bar{X}=\frac{\sum \mathrm{xi}^{*} \mathrm{0i}}{\sum_{\mathrm{oi}}}=\frac{482.24}{780}=0.6191$

Tingkat pelayanan $(\mu)$ :

$=\frac{1}{\text { rata-rata pelayanan } 1 \text { hari }} \times$ Interval waktu

$=\frac{1}{0.6191}$ orang per menit $\times 8$

$=12.923 \approx 13$ orang per 8 menit

$=1.6154 \approx 2$ orang per menit

$=96.922 \approx 97$ orang per jam

4. Menghitung Rata-rata Waktu Pengunjung dalam Antrian

$$
\begin{aligned}
& W q=\frac{\lambda^{2} \mu^{-2}\left(\frac{\lambda}{\mu}\right)^{k-1}}{2(k-1) !\left(k-\frac{\lambda}{\mu}\right)^{2}\left[\sum_{n=0}^{k-1} \frac{\left(\frac{\lambda}{\mu}\right)^{n}}{n !}+\frac{\left(\frac{\lambda}{\mu}\right)^{k}}{(k-1) !\left(k-\frac{\lambda}{\mu}\right)}\right]} \\
& W q=\frac{(1.625)^{2}(1.6154)^{-2}\left(\frac{1.625}{1.6154}\right)^{2-1}}{2(2-1) !\left(2-\frac{1.625}{1.6154}\right)^{2}\left[\sum_{n=0}^{2-1}\left(\frac{\left(\frac{1.625}{1.6154}\right)^{2}}{0 !}\right)\left(\frac{\left(\frac{1.625}{1.6154}\right)^{2}}{1 !}\right)+\frac{\left(\frac{1.625}{1.6154}\right)^{2}}{\left.(2-1) !\left(2-\frac{1.625}{1.6154}\right)\right]}\right.} \\
& W q=\frac{1.0179}{4.0355} \\
& W q=0.2522 \text { menit }
\end{aligned}
$$

5. Menghitung Rata-rata Jumlah Pengunjung dalam Antrian

$$
\begin{aligned}
& L q=\lambda(W q) \\
& L q=(1.625)(0.2522) \\
& L q=0.4099 \approx 1 \text { orang }
\end{aligned}
$$

6. Perhitungan Waktu Rata-rata Waktu Pengunjung dalam Sis

$$
\begin{gathered}
W \boldsymbol{s}=W \boldsymbol{q}+\frac{1}{\mu} \quad \ldots \ldots \ldots \\
W s=0.2522+\frac{1}{1.6154} \\
W s=0.8713 \approx 1
\end{gathered}
$$

7. Menghitung Rata-rata Jumlah Pengunjung dalam Sistem

$L s=\lambda(W s)$

$$
\begin{aligned}
& L s=1.625(0.8713) \\
& L s=1.4158 \approx 2 \text { orang }
\end{aligned}
$$




\section{KESIMPULAN}

1. Model antrian pada sistem antrian SPBU Kopkar Nusa Tigaadalah model antrian

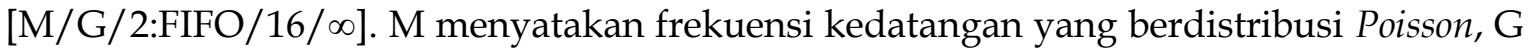
menyatakan waktu pelayanan yang tidak berdistribusi eksponensial, 2 menyatakan jumlah server yang tersedia. Disiplin antrian yang digunakan adalah FIFO (First In First Out) yang berarti pelanggan dilayani berdasarkan urutan kedatangan pelanggan, 16 menyatakan jumlah pelanggan yang bisa masuk ke dalam sistem, $\infty$ menyatakan populasi yang tak terbatas.

2. Dalam hasil analisis terhadap sistem antrian, didapat bahwa rata-rata tingkat kedatangan pelanggan $(\lambda)$ adalah 13 orang per 8 menit, berarti jumlah pengunjung yang datang ke dalam sistem adalah 2 orang tiap menit. Untuk tingkat pelayanan $(\mu)$ nilainya adalah 13 orang per 8 menit yang artinya jumlah pengunjung yang dapat dilayani server dalam 2 menit adalah 1 pengunjung. Tingkat kesibukan atau utilitas server yang diperoleh yaitu $50.3 \%$.

3. Untuk antrian yang terjadi, rata-rata jumlah pengunjung dalam antrian adalah 1 orang, dan rata-rata jumlah pengunjung dalam sistem adalah 1 orang. Waktu tunggu rata-rata pengunjung dalam antrian yang diperoleh adalah 1 menit dan rata-rata lama pengunjung dalam sistem adalah 2 menit.

\section{Saran}

1. Untuk menghilangkan waktu menganggur sebaiknya ada karyawan yang mengatur /menjaga ketertiban lalulintas di sekitar SPBU.

2. Bagi peneliti selanjutnya dapat diembangan analisis model antrian bagi efetifitas dan efisiensi perusaha

Buku :

\section{DAFTAR PUSTAKA}

Haming, Murdifin dan Nurnajamuddin, Mahfud, 2007. Manajemen Produksi ModernOperasi Manufaktur dan Jasa, Buku Satu, Cetakan Pertama, Bumi Aksara, Jakarta.

Kakiay, Thomas J. 2004. Dasar Teori Antrian Untuk Kehidupan Nyata, ANDI, Yogyakarta.

Pangestu Subagyo, M. Asri, T. H. Handoko. 2002. Dasar-Dasar Operational Research, Edisi Kedua, BPFE, Yogyakarta.

Taylor III, Bernard, 2005. Introduction to Management Science; Sains Manajemen, Alih Bahasa, Vita Silvira, Chaerul D. Djakman dan Yanivi S. Baktiar, Buku Dua, EdisiKedelapan, Salemba Empat, Jakarta.

\section{Jurnal :}

Herli Awang, 2013. Jurnal Antrian Konsumen Pada Stasiun Pengisian Bahan Bakar Umum (SPBU) No. 64-75364 Jl. Yos Sudarso II Sangatta, Samarinda. http:// ejurnal.untagsmd.ac.id/index.php/ekm/article/view/339/Diakses Senin, 23 Maret 2015

Sahab Marshel, Komala Erwan dan Siti Nurlaly Kadarini, 2013. Analisis Antrian SPBU (64 78118). Studi Kasus Jl. Hasanudin Pontianak. http://downloadportal.garuda. org/article.php\%3Farticle\%3D111743\%26val\%302310.DiaksesSenin, 23 Maret 2015. 


\section{Internet :}

http://ghostyoen.files.wordpress.com/2008/02/simulasi-antrian.pdfDiakses Senin, 23 Maret 2015.

http://mey20.wordpress.com/edocation/tgs-teori-antrian-2Diakses Senin, 23 Maret 2015. http://digilib.unnes.ac.id/gsdl/collect/skripsi/archives/HASH7e27.dir/doc.pdfDiakses Kamis 26 Maret 2015.

http://thesonofdevil.wordpress.com/2010/01/18/teori-antrian/ Diakses Kamis, 26 Maret 2015. 